\title{
Residual herbicides in Roundup Ready soybean: A case study in multiple years and locations with Ipomoea triloba
}

\section{Herbicidas residuais em soja Roundup Ready: Um caso de estudo de múltiplos anos e locais com Ipomoea triloba}

\author{
Ramiro Fernando Lopez Ovejero' ${ }^{1}$ D, Gilmar José Picoli Junior ${ }^{1}$ (D), \\ Hudson Kagueyama Takano ${ }^{2 *}$ (D), Matheus Palhano' ${ }^{1}$, Philip Westra ${ }^{2}$
}

${ }^{1}$ Bayer Crop Science, Nações Unidas Ave, São Paulo, SP, Brazil

${ }^{2}$ Colorado State University, Fort Collins CO, USA

*Corresponding author: hudsontakano@gmail.com

Received in January 7, 2019 and approved in April 2, 2019

\begin{abstract}
The evolution of glyphosate-resistant and -tolerant weeds has caused changes in weed management around the world. Residual herbicides are crucial tools for weed management, but the rate of adoption by soybean growers remains very low in Brazil. In this research, we used glyphosate tolerant Ipomoea triloba as a model weed species to evaluate the advantages of using residual herbicides on soybeans in multiple years and locations of transition and Cerrado regions of Brazil, rather than relying only on post-emergence control. Most residual herbicides provided enough residual activity to allow a longer application window in post-emergence. Treatments with residual herbicides increased overall weed control, preventing weed interference and increasing soybean yield. When two residual herbicides were used as opposed to only one, a better I. triloba control was achieved, reflecting in higher crop yield, especially in conditions of high weed infestation. The use of pre-emergence herbicides allows growers to have a longer application window for the post-emergence treatment, which is particularly important in Brazilian Cerrado large fields when logistic could be an issue.
\end{abstract}

Index therms: Pre-emergence; weed management; glyphosate resistance; crop yield; weed interference.

\begin{abstract}
RESUMO
A evolução de plantas daninhas resistentes e tolerantes ao glyphosate tem causado mudanças no manejo de plantas daninhas em todo o mundo. Herbicidas residuais são cruciais para o manejo dessas plantas daninhas, porém a taxa de adoção dessas ferramentas ainda é significativamente baixa no Brasil. Nesta pesquisa, Ipomoea triloba tolerante ao glyphosate foi utilizada como uma espécie modelo para avaliar, em múltiplos anos e localidades do Brasil, as vantagens de se utilizar herbicidas residuais em soja, comparado ao controle realizado apenas em pós-emergência. A maioria dos herbicidas residuais proporcionaram atividade residual suficiente para uma janela maior de aplicação em pós-emergência. Tratamentos com herbicidas residuais também aumentaram o controle final de plantas daninhas, prevenindo a interferência inicial com a soja, o que refletiu em maior produtividade. Maiores porcentagens de controle sobre I. triloba foram observadas quando dois herbicidas residuais foram utilizados, em comparação à apenas um, especialmente nos anos e localidades com alta infestação. O uso de herbicidas utilizados em pré-emergência permite uma janela de aplicação maior em pós-emergência, o que pode ser importante em grandes propriedades onde logística constitui um entrave.
\end{abstract}

Termos para indexação: Pré-emergência; manejo de plantas daninhas; resistência a glyphosate; produtividade; matointerferência.

\section{INTRODUCTION}

Brazil plays a key role in global soybean production with the largest cultivated area in the world in 2018-2019. Approximately 37.5 million ha are planted with soybean in Brazil, and the estimated total production is more than 120 million tons (USDA, 2018; Peterson et al., 2018). Among all factors affecting soybean productivity, weeds are considered the number one issue around the world, accounting for $37 \%$ yield losses on average, while only
$22 \%$ of losses are caused by pests and diseases (Oerke; Dehne, 2004; Soltani et al., 2016; 2017).

Weed management in Brazilian soybean production has changed significantly in the past few decades. In the late 1970 's, the use of mechanical weed control in combination with soil-incorporated herbicides that needed to be incorporated in the soil (e.g. trifluralin) was commonplace (Godoy et al., 2015). Ten years later, pre- (e.g. metribuzin) and post-emergence herbicides (e.g. ACCase and ALS 
inhibitors) were rapidly adopted by soybean growers. However, weed resistance to some of these chemicals evolved in a short period of time (Monqueiro et al., 2000; Vidal; Merotto Jr., 1999; Gazziero et al., 2000). When the Roundup Ready soybeans (Monsanto Company, St. Louis, MO) were released in 2005, weeds resistant to ALS inhibitors and ACCase inhibitors were easily managed by glyphosate (Braz et al., 2011). The high efficacy, broadspectrum activity, and low cost provided by glyphosate prompted growers to reduce the use of residual herbicides in their weed management programs (Peterson et al., 2018; Powles, 2008).

The effect of over-reliance on glyphosate for soybean weed control has been the continuous evolution of glyphosate resistant weeds. As of 2018, eight weed species have evolved glyphosate resistance in Brazil (Roman et al., 2004; Carvalho et al., 2011; Santos et al., 2014; Brunharo et al., 2016; Takano et al., 2017; Küpper et al., 2017; Lopez Ovejero et al., 2017). Additionally, a number of naturally glyphosate tolerant species such as Ipomoea triloba, I. grandifolia, Euphorbia heterophylla, and Commelina benghalensis have caused soybean yield losses due to poor glyphosate efficacy on these weeds (Takano et al., 2013).

I. triloba is commonly known as three-lobe morninglory and belongs to the Convolvulaceae family is easily identified by its three-lobed leaves and twining stems (Chauhan; Abugho, 2012). It is native to tropical America and widespread around all regions of Brazil, especially in no-till crop systems due to its large seed size which allows good germination and robust seedling with energy to penetrate the straw layer (Azania et al., 2002). Because glyphosate has not been as efficient as it used to be, the use of pre-emergence herbicides has increased in the United States and Canada (Peters; Strek, 2018), but not as much in others like Brazil and Argentina. This may be attributed to the perception that using residual herbicides is not as simple as post-emergence herbicides, and that several environmental factors can influence their efficacy (e.g. soil moisture, organic matter, soil texture) (Sebastian et al., 2017).

The majority of growers in South America do not see the benefits of using residual herbicides in preventing yield losses by weed interference, especially when postemergence herbicides still provide generally good control. Therefore, it is critical to evaluate multiple-years and -locations to address research questions related to residual herbicides. These studies can demonstrate the benefits of residual soybean herbicides and help growers consider their use. The objective of this research was to compare weed control and crop selectivity provided by herbicide programs including one or two residual herbicides versus those based only on glyphosate.

\section{MATERIAL AND METHODS}

Field trials were conducted in four different locations of Brazil with the same experiment repeated across three consecutive years $(2014,2015$, and 2016) between October and April. Each location corresponded to different environmental conditions: Santa Cruz das Palmeiras (SP), Cachoeira Dourada (MG), Luis Eduardo Magalhães (BA) and Rolândia (PR). The coordinates, soil characteristics, and soybean varieties used in each location are presented in Table 1. Rainfall data were also recorded and presented in Figure 1. Temperature data were also collected but not presented, as there was no effect of temperature on herbicide efficacy.

All fields were free of growing weeds before the experiments were initiated. The weed species present in the experiments included Amaranthus viridis, Ipomoea triloba, and Eleusine indica. In these studies, only I. triloba was evaluated because the other species were present at

Table 1: Coordinates, soil characteristics and soybean variety for each location where experiments were conducted in 2014, 2015 and 2016.

\begin{tabular}{|c|c|c|c|c|c|c|}
\hline Location & State & Coordinates & Soil texture & $\begin{array}{l}\text { Organic } \\
\text { Matter }\end{array}$ & $\mathrm{pH}$ & Variety \\
\hline $\begin{array}{l}\text { Santa Cruz das } \\
\text { Palmeiras }\end{array}$ & São Paulo (SP) & S $21^{\circ} 48^{\prime} ;$ W $47^{\circ} 16^{\prime}$ & Clay & 2.8 & 5.5 & M6410 IPRO \\
\hline Cachoeira Dourada & Minas Gerais (MG) & S 183'; W49²6' & Clay & 1.9 & 5.4 & NA7667 IPRO \\
\hline $\begin{array}{l}\text { Luis Eduardo } \\
\text { Magalhães }\end{array}$ & Bahia (BA) & S $12^{\circ} 07^{\prime} ;$ W $46^{\circ} 01^{\prime}$ & Sandy & 1.6 & 6.0 & MSOY8808 IPRO \\
\hline Rolândia & Paraná (PR) & S $23^{\circ} 16^{\prime} ;$ W $51^{\circ} 29^{\prime}$ & Clay & 3.5 & 4.9 & MSOY5947 IPRO \\
\hline
\end{tabular}


extremely low frequencies $\left(<1\right.$ plant $\left.\mathrm{m}^{-2}\right)$; and were hand removed from the experimental areas. In addition to the native seedbank infestation, I. triloba seeds were planted in all locations and years at 100 seeds $\mathrm{m}^{-2}$. Emerged weed density varied among locations and was recorded at 28 days after soybean emergence (DAE) by counting the number of weeds infesting $0.25 \mathrm{~m}^{2}$, in three random sites within each plot (Table 2).

Soybean was no-till planted in the first week of October for all locations and years. After planting, disease and insect control were utilized following local agronomic practices. Plot dimensions were 3 by $5 \mathrm{~m}$, but the evaluated area included six 4-m soybean rows spaced $0.5 \mathrm{~m}$ between rows $\left(12 \mathrm{~m}^{2}\right.$ per plot). The experimental design was a randomized complete block design with 16 treatments and four replications (Table 3 ). In this research, flumioxazin, sulfentrazone, and imazethapyr were always applied pre-emergence to the soil, and glyphosate was always applied post-emergence to emerged plants. All plots were sprayed with a $\mathrm{CO}_{2}$ backpack sprayer equipped with a 3-m long boom containing six XR110.015 nozzles (TeeJet Technologies, Wheaton,IL), calibrated to deliver
$120 \mathrm{~L} \mathrm{ha}^{-1}$ (pressure of $240 \mathrm{kPa}$ and a speed of $2.9 \mathrm{~km} \mathrm{~h}^{-1}$ ). All treatments were applied in the morning time when wind was less than $1 \mathrm{~m} \mathrm{~s}^{-1}$, temperatures were between 20-25 $\mathrm{C}$, and relative humidity above $70 \%$.

Visual weed control (\%) relative to the nontreated check was conducted 7 days before harvest. Grain yield $\left(\mathrm{kg} \mathrm{ha}^{-1}\right)$ was determine by harvesting two 5 -m-long rows in the center of the plot, weighting and correcting grain humidity to $13 \%$. Assumptions of homogeneity of variance and normality were met via Levene's test and QQ-plot analysis, respectively. As such, no data transformation was necessary. ANOVA was conducted using the emmeans package in $\mathrm{R}$ (Lenth, 2019). Location and year were considered as fixed effects in the ANOVA and the data across years and locations were pooled when the interaction was not significant $(\mathrm{p}<0.05)$. Multiple means grouping test was conducted (Scott Knott) when ANOVA showed significance between treatments $(p<0.05)$. The orthogonal contrast comparison was also employed to compare treatments with residual herbicides, along with residual herbicides versus glyphosate only.
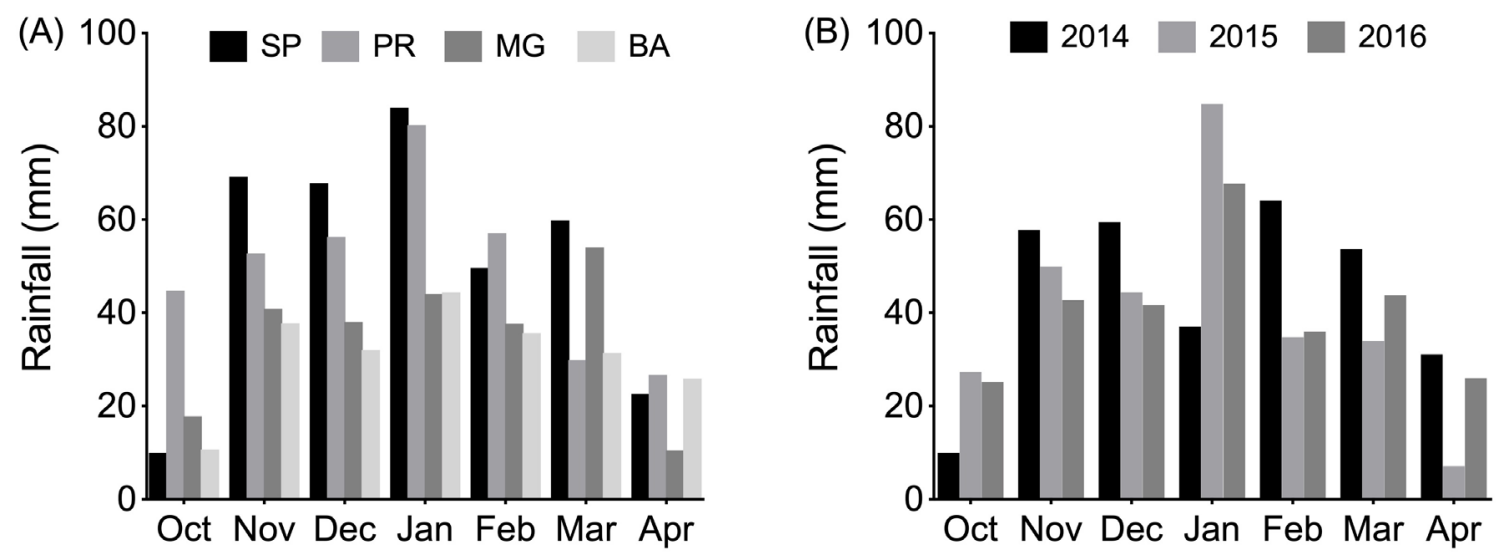

Figure 1: Average of monthly rainfall across the season period by location (A) and by year (B).

Table 2: Density of Ipomoea triloba (plants $\mathrm{m}^{-2}$ ) in the untreated check plots from each location and year.

\begin{tabular}{ccccc}
\hline \multirow{2}{*}{ Location } & \multicolumn{4}{c}{ \# of Ipomoea triloba plants m $^{-2}$} \\
\cline { 2 - 5 } & 2014 & 2015 & 2016 & Average \\
\hline SP & 71 & 79 & 64 & 71 \\
MG & 178 & 27 & 35 & 80 \\
BA & 95 & 9 & 47 & 50 \\
PR & 431 & 188 & 61 & 227 \\
Average & 194 & 76 & 52 & - \\
\hline
\end{tabular}

SP: São Paulo, PR: Paraná, MG: Minas Gerais, BA: Bahia. 
Table 3: Herbicide programs evaluated in each location and year. Doses within parenthesis are in gai or ae ha-1. DAE: days after emergence and (soybean development stage).

\begin{tabular}{ccccc}
\hline \multirow{2}{*}{ Pre-emergence } & \multicolumn{4}{c}{ Post-emergence } \\
\cline { 2 - 5 } & 7 DAE (VE-1) & 14 DAE (V1-2) & 21 DAE (V2-3) & 28 DAE (V3-4) \\
\hline Weeded check1 & - & - & - & - \\
Untreated check & - & - & - & - \\
- & Glyphosate (720) & - & Glyphosate (480) & - \\
Sulfentrazone (300) & Glyphosate (720) & - & - & Glyphosate (480) \\
Sulfentrazone (300) & - & - & Glyphosate (720) & - \\
Flumioxazin (50) & - & - & - & Glyphosate (720) \\
Flumioxazin (50) & - & - & Glyphosate (720) & - \\
Imazethapyr (90) & - & - & - & Glyphosate (720) \\
Imazethapyr (90) & - & - & Glyphosate (720) & - \\
Sulfentrazone (200) / imazethapyr (70) & - & - & Glyphosate (720) & Glyphosate (720) \\
Sulfentrazone (200) / imazethapyr (70) & - & - & \multicolumn{2}{c}{ Glyphosate (720) } \\
Flumioxazin (40) / imazethapyr (70) & - & - & Glyphosate (720) & - \\
Flumioxazin (40) / imazethapyr (70) & - & - & - & Glyphosate (720) \\
Sulfentrazone (200) / imazethapyr (70) & - & Glyphosate (720) & - & Glyphosate (480) \\
Flumioxazin (40) / imazethapyr (70) & - & Glyphosate (720) & - & Glyphosate (480) \\
\hline
\end{tabular}

${ }^{1}$ Weeded check was maintained weed free during the whole time when experiments were conducted.

\section{RESULTS AND DISCUSSION}

The ANOVA showed significant differences $(\mathrm{p}<0.05)$ among locations and years but not for the interaction between location and year (Table 4). Therefore, the data are presented by locations and years but not for each location within years nor each year within locations.

Table 4: ANOVA table for location and year effects on weed control and grain yield.

\begin{tabular}{ccc}
\hline & $F$ & $p$-value \\
\hline $\begin{array}{c}\text { Weed control } \\
\text { Location }\end{array}$ & 25.673 & $0.014^{*}$ \\
Year & 21.134 & $0.003^{*}$ \\
Location x year & 1.243 & $0.064^{\mathrm{ns}}$ \\
\hline Grain yield & & \\
Location & 54.754 & $0.002^{\star}$ \\
Year & 34.157 & $0.005^{\star}$ \\
Location x year & 1.179 & $0.076^{\mathrm{ns}}$ \\
\hline
\end{tabular}

\section{Ipomoea triloba control}

For SP, MG and BA locations with I. triloba infestations of up to 80 plants $\mathrm{m}^{-2}$ (Table 2), the combination of a residual herbicide followed by one glyphosate application provided 75 to $97 \%$ weed control (Table 5). These values differed for each herbicide, but no significant differences were observed between glyphosate treatments at 21 and 28 DAE, except in SP. Treatments containing flumioxazin provided lower residual control compared to sulfentrazone and imazethapyr. When two residual herbicides were combined and followed by one glyphosate application, I. triloba control was as high as $98 \%$. In PR, where weed density was the highest, only treatments with two residual herbicides followed by one or two glyphosate applications showed control greater than $80 \%$.

In general, treatments with glyphosate only provided less Ipomoea triloba control than those with residual herbicides (Table 5). Moreover, weed control levels in São Paulo (SP) and Paraná (PR) was lower than in Minas Gerais (MG) and Bahia (BA), probably due to the higher weed density in these first two locations (Table 2). In 
SP, the treatments with only glyphosate provided less than $70 \%$ control on I. triloba. Similar results were observed by Lopez Ovejero et al., (2013), in which glyphosate alone $(720 \mathrm{~g}$ ae ha-1) controlled $58-73 \%$ of I. triloba. Flumioxazin, followed by glyphosate achieved control below $80 \%$. Similar levels of control were observed for imazethapyr, followed by glyphosate at 14 days after emergence (DAE). Most treatments with two residual herbicides in tank-mix plus glyphosate applications in post-emergence provided high levels ( $>80 \%$ ) of I. triloba control (Table 5).

The lowest levels of control were observed in PR, where two glyphosate applications provided only $50-60 \%$ efficacy, depending on when the second application was done (21 or 28 DAE). Most of the residual herbicides followed by only one glyphosate application provided less than $80 \%$ control in this location. However, when glyphosate was applied two times, after a residual herbicide treatment, more than $90 \%$ control was observed. These findings demonstrate that when weed infestation is high $\left(>100\right.$ plants $\left.\mathrm{m}^{-2}\right)$, only one pre-emergence application might not be sufficient to provide good weed control on glyphosate-tolerant I. triloba.

In $\mathrm{MG}$ and $\mathrm{BA}$, where weed infestation was less than 100 plants $\mathrm{m}^{-2}$ in all years, two glyphosate applications, with no residual treatment, were enough to provide more than $80 \%$ control when the second application occurred at 28 DAE. Most of the residual herbicides combined with one or two glyphosate applications provided higher levels of weed control in these two locations. These results demonstrate that the use of pre-emergence herbicides allow growers to have a longer application window for the postemergence treatment, which is particularly important in Brazilian Cerrado large fields where logistics are an issue.

For all years, treatments with no residual herbicides showed efficacy lower than $80 \%$ (Table 6 ). When at least one residual herbicide plus one glyphosate application, weed control was higher than $80 \%$, especially for treatments with sulfentrazone (87-94\%). When residual herbicides are incorporated into management program, no

Table 5: Percentage of Ipomoea triloba control before soybean harvest in each location. Results are pooled means from the three years $(n=12)$. Means followed by the same letter in each column are not significantly different by the Scott Knott test $(p<0.05)$.

\begin{tabular}{|c|c|c|c|c|c|c|c|c|}
\hline \multirow{2}{*}{ Treatment } & \multicolumn{8}{|c|}{ I. triloba control (\%) } \\
\hline & $\mathrm{SP}$ & & MG & & $\mathrm{BA}$ & & PR & \\
\hline Weeded check & 100 & $a$ & 100 & $a$ & 100 & $a$ & 100 & $a$ \\
\hline Untreated check & 0 & e & 0 & e & 0 & $d$ & 0 & $f$ \\
\hline gly¹/gly ${ }^{2}$ & 63 & $d$ & 77 & $d$ & 53 & c & 50 & e \\
\hline gly $^{1} /$ gly $^{3}$ & 68 & $d$ & 92 & $b$ & 80 & $b$ & 60 & d \\
\hline sulf $^{4} /$ gly $^{2}$ & 92 & $\mathrm{~b}$ & 93 & $b$ & 95 & $a$ & 78 & c \\
\hline sulf ${ }^{4} /$ gly $^{3}$ & 87 & $b$ & 94 & $b$ & 97 & $a$ & 87 & b \\
\hline flum ${ }^{4} /$ gly ${ }^{2}$ & 78 & c & 87 & c & 81 & $b$ & 74 & c \\
\hline flum 4 / gly ${ }^{3}$ & 79 & c & 90 & $b$ & 78 & $\mathrm{~b}$ & 68 & d \\
\hline $\operatorname{imaz}^{4} /$ gly ${ }^{2}$ & 75 & c & 90 & $b$ & 96 & $a$ & 74 & c \\
\hline $\operatorname{imaz}^{4} / g y^{3}$ & 88 & $b$ & 90 & $b$ & 92 & a & 60 & d \\
\hline sulf + imaz $^{4} /$ gly $^{2}$ & 84 & $b$ & 93 & $b$ & 98 & $a$ & 64 & $d$ \\
\hline sulf + imaz $^{4} /$ gly $^{3}$ & 82 & $b$ & 93 & $b$ & 96 & a & 76 & c \\
\hline flum + imaz ${ }^{4}$ / gly ${ }^{2}$ & 88 & $b$ & 86 & c & 98 & a & 74 & c \\
\hline flum + imaz ${ }^{4}$ / gly ${ }^{3}$ & 85 & $b$ & 88 & c & 98 & a & 72 & c \\
\hline sulf + imaz $^{4} /$ gly $^{2} /$ gly $^{3}$ & 92 & $b$ & 93 & $b$ & 96 & a & 92 & b \\
\hline flum + imaz / gly $/$ gly 3 & 87 & $\mathrm{~b}$ & 93 & $\mathrm{~b}$ & 99 & a & 90 & $\mathrm{~b}$ \\
\hline $\mathrm{F}$ & 24 & & 144 & & 54 & & 53 & \\
\hline $\mathrm{CV}$ & 18 & & 8 & & 15 & & 17 & \\
\hline
\end{tabular}

17 days after emergence (DAE), ${ }^{2} 14 \mathrm{DAE},{ }^{3} 28 \mathrm{DAE},{ }^{4}$ Pre-emergence; SP: São Paulo, PR: Paraná, MG: Minas Gerais, BA: Bahia. 
significant differences are observed between glyphosate applications at 21 or 28 DAE. Imazethapyr and flumioxazin used alone provided intermediate levels of control (70$85 \%$ ), even when weed density was lower in years 2015 and 2016 (Table 2).

Table 6: Percentage Ipomoea triloba control before soybean harvest each year. Results are pooled means from the four locations $(n=16)$. Means followed by the same letter in each column are not significantly different by the Scott Knott test $(p<0.05)$.

\begin{tabular}{|c|c|c|c|c|c|c|}
\hline \multirow{2}{*}{ Treatments } & \multicolumn{6}{|c|}{ I. triloba control (\%) } \\
\hline & 2014 & & 2015 & & 2016 & \\
\hline Weeded check & 100 & $a$ & 100 & $a$ & 100 & $\mathrm{a}$ \\
\hline Untreated check & 0 & $f$ & 0 & $\mathrm{e}$ & 0 & $f$ \\
\hline gly $^{1} /$ gly $^{2}$ & 56 & $\mathrm{e}$ & 68 & $d$ & 71 & $\mathrm{e}$ \\
\hline gly $^{1} /$ gly $^{3}$ & 77 & $d$ & 75 & $d$ & 72 & $d$ \\
\hline sulf $^{4} /$ gly $^{2}$ & 87 & $\mathrm{~b}$ & 89 & $b$ & 92 & $b$ \\
\hline sulf $^{4} /$ gly $^{3}$ & 88 & $\mathrm{~b}$ & 94 & $b$ & 93 & $\mathrm{~b}$ \\
\hline flum $^{4} /$ gly ${ }^{2}$ & 69 & $d$ & 81 & $\mathrm{c}$ & 71 & $d$ \\
\hline flum $^{4} /$ gly $^{3}$ & 75 & $d$ & 88 & $b$ & 72 & $d$ \\
\hline $\operatorname{imaz}^{4} / g^{\prime} y^{2}$ & 74 & $d$ & 80 & $\mathrm{c}$ & 78 & $\mathrm{c}$ \\
\hline $\mathrm{imaz}^{4} / \mathrm{gly}^{3}$ & 73 & $d$ & 86 & $\mathrm{~b}$ & 82 & c \\
\hline sulf + imaz $^{4} / g y^{2}$ & 88 & $b$ & 84 & $\mathrm{~b}$ & 83 & $c$ \\
\hline sulf + imaz $/$ gly $^{3}$ & 84 & $\mathrm{~b}$ & 92 & $b$ & 84 & c \\
\hline flum + imaz ${ }^{4}$ gly² & 82 & C & 80 & $\mathrm{C}$ & 83 & $\mathrm{C}$ \\
\hline flum + imaz ${ }^{4} /$ gly $^{3}$ & 80 & c & 93 & $\mathrm{~b}$ & 84 & $\mathrm{c}$ \\
\hline sulf $+\mathrm{imaz}^{4} / \mathrm{gly}^{2} / \mathrm{gly}^{3}$ & 94 & $\mathrm{~b}$ & 97 & $b$ & 90 & $\mathrm{~b}$ \\
\hline flum + imaz / gly² / gly & 89 & $\mathrm{~b}$ & 96 & $\mathrm{~b}$ & 92 & $\mathrm{~b}$ \\
\hline $\mathrm{F}$ & 54 & & 43 & & 55 & \\
\hline $\mathrm{CV}$ & 15 & & 18 & & 16 & \\
\hline
\end{tabular}

Two residual herbicides plus two glyphosate applications provided consistent control in all years, although more than one glyphosate application may not be a preferred strategy for mitigating evolution of herbicide resistance. In 2014, the highest efficacy on I. triloba was observed for two residual herbicides, followed by two glyphosate applications (Table 6). Sulfentrazone alone or in tank mix with imazethapyr plus glyphosate also provided more than $85 \%$ control. Flumioxazin or imazethapyr, followed by glyphosate showed less than $80 \%$ control, but their pre-emergence tank-mix, complemented with glyphosate, provided good efficacy $(80-82 \%)$. The two treatments with only glyphosate provided 56 and $77 \%$ control when the second application occurred at 21 and 28 DAE, respectively. Unlike the treatments with only glyphosate, all treatments with residual herbicides provided good control of I. triloba in 2015. In 2016, flumioxazin followed by glyphosate provided the same levels of control as those treatments with only two glyphosate applications. All other treatments with residual herbicides provided good control on I. triloba, especially with sulfentrazone or when glyphosate was applied two times after the pre-emergence treatment. The lower levels of weed control in the first year compared to the other two following years might be associated with the lower rainfall observed for October 2014, when residual herbicides were applied (Figure 1B).

Soybean yield. Yield losses due to I. triloba interference in the untreated check from each location were $77,83,64$ and $70 \%$ for SP, PR, MG and BA, respectively (Table 7). Similarly, yield losses by Ipomoea species interference, reduced soybean yield 25 to $43 \%$ with low density ( 2 to 8 plants $\mathrm{m}^{-2}$ ) and up to $90 \%$ under high densities ( $>20$ plants $\mathrm{m}^{-2}$ ) (Howe; Oliver,1987). All treatments were considered safe to the crop in SP, and differences in weed control did not reflect on differences in yield because all herbicide treatments provided similar productivity. When sulfentrazone (300 $\mathrm{g}$ ai ha $\left.\mathrm{ha}^{-1}\right)$ followed by glyphosate ( $1200 \mathrm{~g}$ ae ha $\left.{ }^{-1}\right)$, no yield losses were observed (Osipe et al., 2014). In PR, where was observed the highest weed density the two treatments with only glyphosate applied yielded less than the weeded check, probably due to the low efficacy observed in these treatments. For similar reason, the treatments with flumioxazin or imazethapyr alone provided poor I. triloba control in PR (high infestation areas in all years) (Table 8), which also led to decreased soybean yield when compared to the weeded check. In MG and BA, all treatments with residual herbicides provided the same yields as the weeded check, demonstrating that those treatments were safe to the crop and provided good weed control. On the other hand, when relying on only glyphosate, less crop yield was obtained, probably because of the poor weed control provided by these treatments.

When analyzing the yield data by year, the two treatments with two residual herbicides plus two glyphosate applications provided high yield, similar to the weeded check. The other treatments with either glyphosate only or one residual, plus glyphosate showed less yield than the weeded check. This is probably because weed 
infestation in all locations were generally higher in 2014 than in the following two years. For 2015 and 2016, crop yield was higher when residual herbicides were used compared to when weed management was based only on glyphosate, except when the second glyphosate application was sprayed at 28 DAE in 2016.

Table 7: Grain yield (kg ha-1) for each herbicide program treatment across the four locations. Results are pooled means from the three years $(n=12)$. Means followed by the same letter in each column are not significantly different by the Scott Knott test $(p<0.05)$.

\begin{tabular}{|c|c|c|c|c|}
\hline \multirow{2}{*}{ Treatment } & \multicolumn{4}{|c|}{ Grain yield $\left(\mathrm{kg} \mathrm{ha}^{-1}\right)$} \\
\hline & SP & PR & MG & BA \\
\hline Weeded check & $5216 a$ & $4749 a$ & $3090 a$ & $3352 a$ \\
\hline Untreated check & $1205 b$ & $828 \mathrm{c}$ & $1128 c$ & 995 c \\
\hline gly ${ }^{1} /$ gly $^{2}$ & $5049 a$ & $4118 b$ & $2649 b$ & $2975 b$ \\
\hline gly $/$ gly 3 & $5395 a$ & $4235 b$ & $2751 b$ & $2893 b$ \\
\hline sulf $/$ gly $^{2}$ & $5527 a$ & $4467 a$ & $3571 a$ & $3114 a$ \\
\hline sulf ${ }^{4} /$ gly $^{3}$ & $5434 a$ & $4568 a$ & $3064 a$ & $3128 a$ \\
\hline flum $^{4} /$ gly $^{2}$ & $5096 a$ & $4065 b$ & $3415 a$ & $3156 a$ \\
\hline flum $^{4} /$ gly $^{3}$ & $5302 a$ & $4031 \mathrm{~b}$ & $3238 a$ & $3162 a$ \\
\hline $\operatorname{imaz}^{4} / g^{\prime} y^{2}$ & $5505 a$ & $3724 b$ & $3240 a$ & $3268 a$ \\
\hline $\operatorname{imaz}^{4} / g \mid y^{3}$ & $4995 a$ & $4098 b$ & $3090 a$ & $3373 a$ \\
\hline sulf + imaz / gly ${ }^{2}$ & $5302 a$ & $4677 a$ & $3429 a$ & $3254 a$ \\
\hline sulf + imaz $^{4} /$ gly $^{3}$ & $5446 a$ & $4492 a$ & $3151 a$ & $3309 a$ \\
\hline flum + imaz ${ }^{4}$ gly² & $5205 a$ & $4356 a$ & $3257 a$ & $3466 a$ \\
\hline flum + imaz ${ }^{4}$ gly ${ }^{3}$ & $5293 a$ & $4486 a$ & $2998 a$ & $3350 a$ \\
\hline sulf $+\mathrm{imaz}^{4} / \mathrm{gly}^{2} / \mathrm{gly}^{3}$ & $5432 a$ & $4528 a$ & $3361 \mathrm{a}$ & $3205 a$ \\
\hline flum + imaz ${ }^{4} /$ gly $^{2} /$ gly $^{3}$ & $5555 a$ & $4614 a$ & $3300 a$ & $3260 a$ \\
\hline $\mathrm{F}$ & 42 & 27 & 17 & 20 \\
\hline CV & 11 & 13 & 16 & 14 \\
\hline
\end{tabular}

17 days after emergence (DAE), ${ }^{2} 14 \mathrm{DAE},{ }^{3} 28 \mathrm{DAE},{ }^{4}$ Pre-emergence; SP: São Paulo, PR: Paraná, MG: Minas Gerais, BA: Bahia.

The orthogonal contrasts show that including residual herbicides in the management program provides higher I. triloba control and soybean yield, compared to managing weeds with only glyphosate in Roundup Ready soybean (Figure 2A-B). The increase in yield with residual herbicides can be mainly attributed to two factors. First, residual herbicides avoid initial weed interference when soybean plants are still emerging (Constantin et al., 2007). Residual herbicides also delay weed emergence and provide a better condition for the post-emergence treatments to work efficiently (e.g. smaller weed size) (Osipe et al., 2014). In the same way, the contrasts between using one residual vs two residual herbicides are also significant for I. triloba control and soybean yield (Figure 2C-D). Mixing two residual herbicides with different modes of action not only can increase the spectrum of weed control but also delay the evolution of weed resistance (Norsworthy et al., 2012). The contrast for one glyphosate application $v s$ two glyphosate applications was also significant for I. triloba control but not for grain yield (Figure 2E-F). However, when weed density was high as observed in PR, two glyphosate applications increased control and, consequently, increased yield (Table 5 and Table 7). Nevertheless, it is important to highlight that managing weeds with herbicides only, is not sustainable. Crop rotation and cover crop use have been proven to be the efficient methods for complementing chemical control in herbicide resistance/tolerance management (Beckie; Reboud, 2009; Marochi et al., 2018; Palhano et al., 2018).

Table 8: Grain yield $\left(\mathrm{kg} \mathrm{ha}^{-1}\right)$ for each herbicide program treatment across the three years. Results are pooled means from the four locations $(n=16)$. Means followed by the same letter in each column are not significantly different by the Scott Knott test $(p<0.05)$.

\begin{tabular}{|c|c|c|c|c|c|c|}
\hline \multirow{2}{*}{ Treatment } & \multicolumn{6}{|c|}{ Grain yield $\left(\mathrm{kg} \mathrm{ha}^{-1}\right)$} \\
\hline & 2014 & & 2015 & & 2016 & \\
\hline Weeded check & 4163 & $a$ & 3735 & $a$ & 4408 & $\mathrm{a}$ \\
\hline Untreated check & 1386 & c & 413 & c & 1159 & c \\
\hline gly ${ }^{1} /$ gly $^{2}$ & 3755 & $b$ & 3126 & $b$ & 4526 & a \\
\hline gly / gly 3 & 3636 & $\mathrm{~b}$ & 3057 & $b$ & 4113 & $b$ \\
\hline sulf $^{4} /$ gly $^{2}$ & 4063 & $\mathrm{a}$ & 3749 & a & 4697 & $\mathrm{a}$ \\
\hline sulf $^{4} /$ gly $^{3}$ & 3962 & $\mathrm{a}$ & 3812 & $\mathrm{a}$ & 4671 & a \\
\hline flum $^{4} /$ gly ${ }^{2}$ & 3589 & $b$ & 3636 & a & 4574 & a \\
\hline flum $^{4} /$ gly 3 & 3572 & $b$ & 3592 & $a$ & 4861 & a \\
\hline $\operatorname{imaz}^{4} / g y^{2}$ & 3643 & $b$ & 3462 & $a$ & 4697 & a \\
\hline $\operatorname{imaz}^{4} /$ gly $^{3}$ & 3630 & $\mathrm{~b}$ & 3414 & $\mathrm{a}$ & 4623 & $\mathrm{a}$ \\
\hline sulf $+\operatorname{imaz}^{4} / \mathrm{gly}^{2}$ & 3715 & $\mathrm{~b}$ & 3667 & $a$ & 4815 & a \\
\hline sulf $+\mathrm{imaz}^{4} / \mathrm{gly}^{3}$ & 3824 & $\mathrm{~b}$ & 3533 & a & 4791 & a \\
\hline flum $+i m a z^{4} /$ gly $^{2}$ & 3757 & $\mathrm{~b}$ & 3388 & $\mathrm{a}$ & 4768 & a \\
\hline flum + imaz ${ }^{4}$ gly ${ }^{3}$ & 3688 & $\mathrm{~b}$ & 3793 & a & 4588 & a \\
\hline sulf $+\mathrm{imaz}^{4} / \mathrm{gly}^{2} / \mathrm{gly}^{3}$ & 4015 & $a$ & 3772 & a & 4777 & a \\
\hline flum + imaz ${ }^{4}$ gly $^{2} /$ gly $^{3}$ & 3913 & a & 3772 & a & 4862 & a \\
\hline $\mathrm{F}$ & 20 & & 29 & & 45 & \\
\hline CV & 15 & & 17 & & 11 & \\
\hline
\end{tabular}




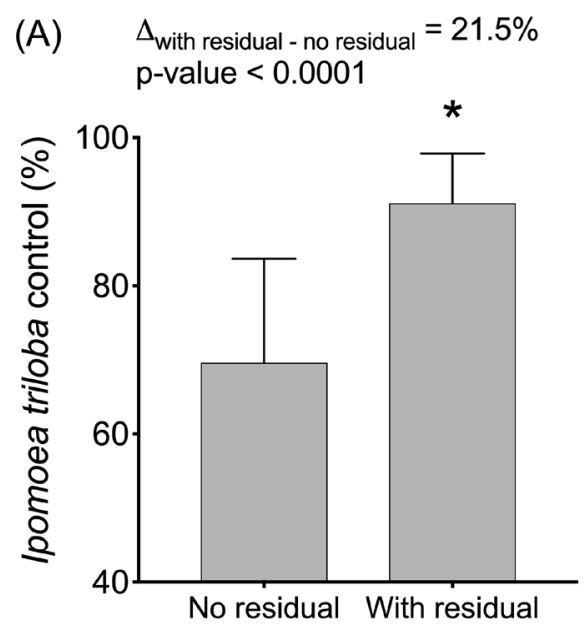

(C) $\quad \Delta_{\text {one residual - two residuals }}=9 \%$ p-value $=0.0012$

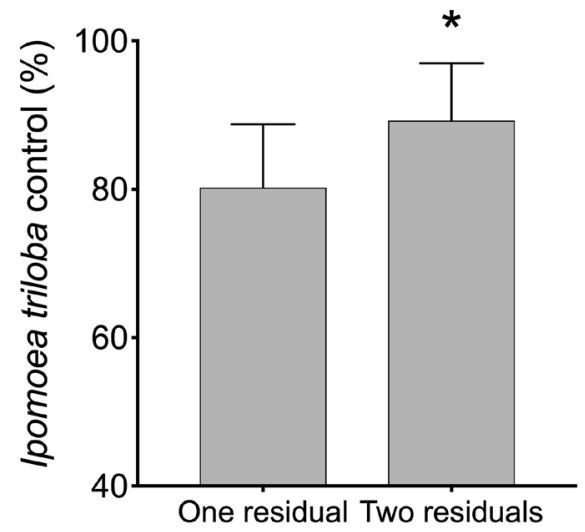

(E) $\quad \Delta_{1}$ gly applic. -2 gly applic. $=10.6 \%$ p-value $=0.0018$

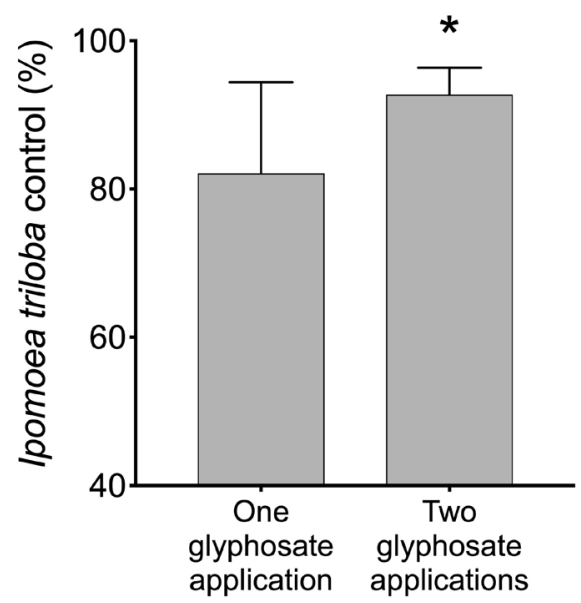

(B) $\quad \Delta_{\text {with resid. - no resid. }}=585 \mathrm{~kg} \mathrm{ha}^{-1}$ p-value $=0.0138$

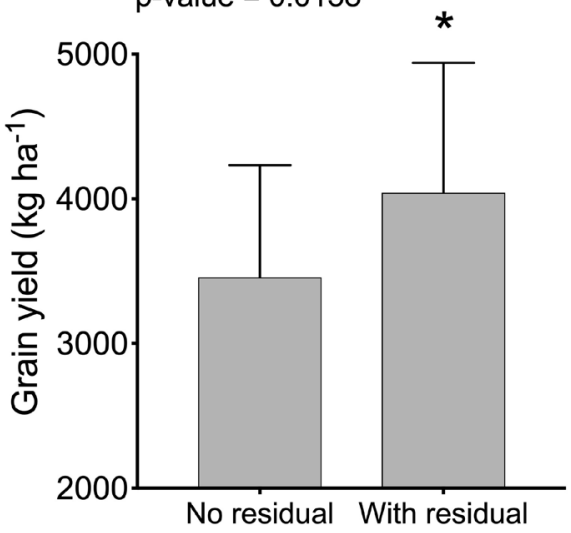

(D) $\quad \Delta_{\text {with resid. - no resid. }}=284 \mathrm{~kg} \mathrm{ha}^{-1}$ p-value $=0.0382$

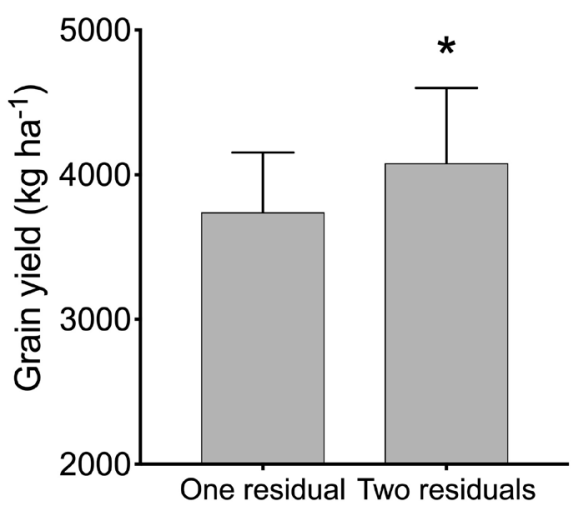

(F) $\quad \Delta_{1}$ gly applic. -2 gly applic. $=182 \mathrm{~kg} \mathrm{ha}^{-1}$ $\mathrm{p}$-value $=0.1454$

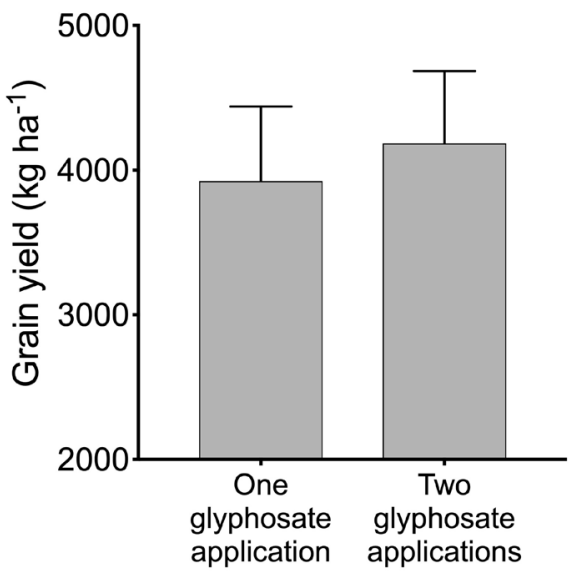

Figure 2: Orthogonal contrasts for Ipomoea triloba control and soybean yield between treatments with residual vs no residual herbicides [T5 to T14 vs T3 and T4] (A and B), one vs two different residual herbicides [T5 to T10 vs T11 to T16] (C and D), and one vs two glyphosate applications [T5 to T14 vs T3, T4, T15 and T16 (E and F). 


\section{CONCLUSIONS}

Most pre-emergence herbicides provided enough residual activity to allow a longer application window in post-emergence. When including residual herbicides in the weed management program, levels of I. triloba control were higher than when using only glyphosate in postemergence. Two residual herbicides in tank mix provided increased weed control compared to only one. This enhanced weed control with residual herbicides resulted in higher levels of soybean yield by preventing initial weed interference. However, for those locations where weed pressure was high, it was necessary to complement weed control with at least one post-emergence treatment to prevent yield losses.

\section{ACKNOWLEDGEMENTS}

We thank Drs. Chandrashekar Aradhya, Nicholas Steppig, and Alexandre Gemelli for their useful comments on manuscript drafts. This research was funded by Bayer CropScience and we declare no conflict of interest.

\section{REFERENCES}

AZANIA, A. A. P. M. et al. Interferência da palha de canade-açúcar (Saccharum spp.) na emergência de espécies de plantas daninhas da família convolvulaceae. Planta Daninha, 20(2):207-212, 2002.

BECKIE, H. J.; REBOUD, X. Selecting for weed resistance: Herbicide rotation and mixture. Weed Technology, 23(1):363-370, 2009.

BRAZ, G. B. P. et al. Herbicidas alternativos no controle de Bidens pilosa e Euphorbia heterophylla resistentes a inibidores de ALS na cultura do algodão. Revista Brasileira de Herbicidas, 10(2):74-85, 2011.

BRUNHARO, C. A. et al. Confirmation and mechanism of glyphosate resistance in tall windmill grass (Chloris elata) from Brazil. Pest Management Science, 72(9):1758-1764, 2016.

CARVALHO, L. B. et al. Detection of sourgrass (Digitaria insularis) biotypes resistant to glyphosate in Brazil. Weed Science, 59(2):171-176, 2011.

CHAUHAN, B. S.; ABUGHO, S. B. Threelobe morningglory (Ipomoea triloba) germination and response to herbicides. Weed Science, 60(2):199-204, 2012.

CONSTANTIN, J. et al. Estimativa do período que antecede a interferência de plantas daninhas na cultura da soja, var.
Coodetec 202, por meio de testemunhas duplas. Planta Daninha, 25(2):231-237, 2007.

GAZZIERO, D. L. et al. Alexandergrass (Brachiaria plantaginea) resistance to ACCase inhibitor herbicides. Planta Daninha, 18(1):169-180, 2000.

GODOY, C. V. et al. Brazilian soybean pest management and threats to its sustainability. Outlooks on Pest Management, 26(3):113-7, 2015.

HOWE, O. W.; OLIVER, L. R. Influence of soybean (Glycine max) row spacing on pitted morninglory (Ipomoea lacunosa) interference. Weed Science, 35(2):185-193, 1987.

KÜPPER, A. et al. Multiple resistance to glyphosate and acetolactate synthase inhibitors in Palmer amaranth (Amaranthus palmeri) identified in Brazil. Weed Science, 65(3):317-326, 2017.

LENTH, R. Emmeans package: Estimated Marginal Means, aka Least-Squares Means. R package version 1.3.3. Available at: <https://CRAN.R-project.org/package=emmeans>. Accessed on: April, 16, 2019.

LOPEZ OVEJERO, R. F. et al. Residual herbicides in weed management for glyphosate-resistant soybean in Brazil. Planta Daninha, 31(4):947-59, 2013.

LOPEZ OVEJERO, R. F. et al. Frequency and dispersal of glyphosate-resistant sourgrass (Digitaria insularis) populations across Brazilian agricultural production areas. Weed Science, 65(2):285-94, 2017.

MAROCHI, A. et al. Managing glyphosate-resistant weeds with cover crop associated with herbicide rotation and mixture. Ciência e Agrotecnologia, 42(4):381-94, 2018.

MONQUEIRO, P. A. et al. Resistência de plantas daninhas aos herbicidas inibidores da ALS na cultura da soja (Glycine max). Planta Daninha, 18(3):419-425, 2000.

NORSWORTHY, J. K. et al. Reducing the risks of herbicide resistance: Best management practices and recommendations. Weed Science, 60(sp1):31-62, 2012.

OERKE, E. C.; DEHNE, H. W. Safeguarding production losses in major crops and the role of crop protection. Crop Protection, 3(4):275-285, 2004.

OSIPE, J. B. et al. Seletividade de aplicações combinadas de herbicidas em pré e pós-emergência para a soja tolerante ao glyphosate. Bioscience Journal, 30(3):110-120, 2014.

PALHANO, M. G. et al. Cover crops suppression of palmer amaranth (Amaranthus palmeri) in cotton. Weed Technology, 32(1):60-65, 2018. 
PETERS, B.; STREK, H. J. Herbicide discovery in light of rapidly spreading resistance and ever-increasing regulatory hurdles. Pest Management Science, 74(10):1154-1164, 2018.

PETERSON, M. A. et al. The challenge of herbicide resistance around the world: A current summary. Pest Management Science, 74(10):2246-2259, 2018.

POWLES, S. B. Evolved glyphosate-resistant weeds around the world: Lessons to be learnt. Pest Management Science, 64(4):360-365, 2008.

ROMAN, E. S. et al. Resistência de azevém (Lolium multiflorum) ao herbicida glyphosate. Planta Daninha, 22(2):301-306, 2004.

SANTOS, G. et al. Conyza sumatrensis: A new weed species resistant to glyphosate in the Americas. Weed Biology and Management, 14(2):106-114, 2014.

SEBASTIAN, D. J. et al. Influence of soil properties and soil moisture on the efficacy of indaziflam and flumioxazin on Kochia scoparia L. Pest Management Science, 73(2):444451, 2017.
SOLTANI, N. et al. Potential corn yield losses from weeds in North America. Weed Technology, 30(4):979-984, 2016.

SOLTANI, N. et al. Perspectives on potential soybean yield losses from weeds in North America. Weed Technology, 31(1):148-154, 2017.

TAKANO, H. K. et al. Efeito da adição do 2, 4-D ao glyphosate para o controle de espécies de plantas daninhas de difícil controle. Revista Brasileira de Herbicidas, 12(1):1-13, 2013

TAKANO, H. K. et al. Goosegrass resistant to glyphosate in Brazil. Planta Daninha, 35:e017163071, 2017.

USDA. World Agricultural Production. Circular Series, WAP 03-17. Available in: <https://apps.fas.usda. gov/psdonline/circulars/production.pdf> Access in: November, 01, 2018.

VIDAL, R. A.; MEROTTO JR, A. Resistência de amendoimbravo aos herbicidas inibidores da enzima acetolactato sintase. Planta Daninha, 17(3):367-373, 1999. 